\title{
Diluted optimism at Osaka
}

\section{Osake}

THE city of Osaka made its bid last week to establish itself as the Japanese "capital of biotechnology" with what was billed as "the first international conference on biotechnology". While that may be something of an exaggeration, the conference, thanks to generous support from the regional government, must have been about the first to hear experts from the Soviet Union describe their national biotechnology programmes alongside executives from many of the major biotechnology companies - Cetus, Calgene, Cytogen, Biogen, BioEurope and the like.

Within Japan, the Kansai region (which includes Osaka, Kyoto and Kobe) can fairly claim to have taken the lead in traditional rivalry with Kanto (the TokyoYokohama megalopolis). Many of Japan's biotechnology companies have their research laboratories in the region, while Kyoto and Osaka University dominate basic research in molecular biology.

The state of international rivalry is harder to assess. Although Japan and the United States often regard themselves as the only players in the game, the European Communities representative was keen to scotch the view that Europe is not an active commercializer of new ideas. It was pointed out that most of the new (if still few) products of biotechnology were first produced in Europe: monoclonal pregnancy test kits (the Netherlands, 1980), biochemically produced human insulin (Denmark, 1982), recombinant amylase (Denmark, 1982) and recombinant $\alpha$ interferon (Austria, 1985). Europe is also far ahead of the rest of the world in building new biotechnology research centres and providing integrated courses of study in the universities.

The UK outlook was more gloomy Some praise was given to the establishment of new companies such as Celltech with "intellectual assets from the public sector and financial assets from the private". But there was a warning that lack of funds in Britain had pushed basic research to the brink of an irreversible decline; there may soon be nothing new to commercialize.

Japan's biotechnology industries are seen as building a better base for the longterm future. At present, commercial emphasis in the United States and Europe is on the production of new pharmaceuticals. That is where, in the relatively near future, completely new products, and new sources of profit, can be created. But it is in plant agriculture and food processing that the really huge returns on investment can be expected towards the end of the century. A very wide spread of companies in Japan has set up biotechnology research laboratories and knowledge of biotechnology is diffused through all kinds of in- dustry. This diversity may pay dividends.

The Japanese tradition of focusing on production technology, rather than on an exotic end-product, is also at work in biotechnology. There is massive investment in exploiting biotechnology to improve existing processes - better bioreactors, enzymes, lipids and surfactants.

That biotechnology research is concentrated in large companies may also work in Japan's favour. A couple of years ago, Japan was bemoaning its lack of new venture capital while the United States was celebrating the host of innovative small companies into which the stock market was pouring money. But now there is a feeling that new venture businesses will not be big enough to capitalize properly on their innovative achievements.

Not everyone was worried about international competition. The high level of cross-licensing agreements that has characterized the first phase of the growth of biotechnology, together with the diversity of uses to which biotechnology may be put, was seen by some as ruling out the kind of national rivalries found in electronics. But representatives from the SouthEast Asian countries were pessimistic. Dependent as many of them are on agricultural production, they stand to benefit most from biotechnology. But they have neither the facilities nor the manpower for large-scale research; recent developments, such as the succesful patenting of new types of seeds, have them worried. The low attendance at lectures given by South-East Asian representatives must have helped confirm their fears.

Alun Anderson

\section{Computerspeak}

\section{Hope for international standards}

\section{Washington}

THE world is one year away from agreeing fundamental standards for controlling the communication of computers, according to the leader of the British delegation at a crucial set of meetings held during the past two weeks in North America. The negotiations involve more than half a dozen countries whose governments have been the most active since 1977 in attempting to arrive at a set of standards for intercomputer communications. The 300 or more delegates are here to discuss the latest development in Open Systems Interconnection (OSI).

The delegates are members of the subcommittees from the Geneva-based International Organisation for Standardisation and represent trade associations and government institutions. The main political impetus has come from the United States, Britain, Japan, West Germany, France, Canada and Scandinavia. The OSI meetings require the countries involved to move towards agreement on a comprehensive package of standards in seven distinct areas. These include the disciplines on how computers should be connected to telecommunications circuits, how those data can be stored and displayed, how one network can communicate with another to allow the "global addressing of computers", how errors in data in the network can be detected and corrected, how messages can be synchronized and their delivery controlled. The other standards enable types of data to be identified as they are transferred between computers over national boundaries and between different computer systems.

The sessions have been taking place in Toronto, Gaithersburg (Maryland), Syracuse (New York) and Durham (North Carolina)

Bryan Wood, leader of the UK delega- tion, says "there is increasing support for a single standard independent of manufacturer". That indeed is the wish of the British government, which has refused to allow the UK telecommunications authority British Telecom to join with IBM to operate a data management network on the grounds that such a partnership would stifle competing systems and allow IBM's own standards to dominate. The IBM communications standard, recognized as a possible rival to OSI, is called System Network Architecture (SNA), and is still being developed in parallel with OSI.

The Europeans and Americans in particular hope that SNA will not hamper OSI development but that it will be used for intercommunications between IBM computers and that the OSI standard will be used for any other communication. The seven levels of the OSI standards, which are at various stages of ratification, are also meant to accommodate communications from any closed network to another.

Computers connected to each other within a factory or office complex would be examples of closed loops, called local area networks (LANs). Such networks will be able to be connected to each other using the OSI standards. They will be able to communicate with each other over an interconnecting network, possibly an international one, whatever the standard used at the local end. The Ethernet system originally devised by Rank Xerox and the recently announced IBM token ring, both forms of LAN, will be accommodated by the OSI standards, claim the delegates to the American conferences.

Bill Johnstone

Bill Johnstone, on sabbatical from his post as technology correspondent of The Times of London, will be writing on technology subjects for Nature during the next few weeks. 